\title{
CONDITIONS ON CONDITIONAL MOOD
}

\author{
HUBA BARTOS
}

Research Institute for Linguistics Hungarian Academy of Sciences

Benczúr utca 33.

H-1068 Budapest

Hungary

bartos@nytud.hu

\begin{abstract}
This paper argues that conditional mood morphology in Hungarian is the spellout of a morphosyntactic feature $\operatorname{excl}(w)$, the semantic interpretation of which is modal exclusion, i.e., counterfactuality. In certain cases (such as wishes, or CF conditionals) this feature is lexically specified on $\mathrm{M}$ [ood], with the direct interpretive aim of counterfactuality, while in others $\mathrm{M}$ has this feature unvalued, and inherits its value from the category Mod[ality] in a standard AGREE relation. The strong interrelation between $\mathrm{M}$ and Mod also manifests in scope phenomena earlier analysed as scope inversion between Mod and T[ense], but can now be accounted for in a more principled way. Finally, it is shown that, unlike what is found in many other languages, Hungarian cannot use tense marking as the exponent of $\operatorname{excl}(w)$, because its "tense" is relative, rather than deictic. Therefore, this language makes use of mood morphology to encode $\mathrm{CF}$, in the particular form of conditional mood.
\end{abstract}

Keywords: mood, modality, tense, counterfactuality, scope

\section{Introduction}

In modern grammatical theory, the analysis of mood has been a rather understudied subject, and even within this relative poverty, the most neglected of all moods has been conditional mood. While the morphology and phonology of mood marking usually does not bring up very peculiar points (though in the particular case of Hungarian, the morphological 
complementarity of overt mood and tense marking is such a point), ${ }^{1}$ its syntactic background, and especially its semantic contribution is still a poorly understood area today. This paper aims to shed at least some light on the interplay between the morphosyntax and semantics of conditional mood in Hungarian, capitalizing on observations about its apparent scopal behavior (Bartos 2003), and about its semantics (Eszes 2004), as well as Iatridou's (2000) ideas on the notion of counterfactuality.

The leading idea of the paper is that Hungarian conditional mood marking covers a range of various semantic features, and on the level of syntax and semantics, mood, in general, is strongly interlinked with the notion of modality. One of the most obvious roles of conditional mood in this language is to denote counterfactuality, and it plays this role, often assumed by tense marking in other languages, because tense marking in Hungarian is not suitable for this.

\section{The data}

\subsection{Bartos (2003)}

Bartos (2003) observed (and gave a syntactic account of) scopal interaction between the three interpretable inflectional morphemes on Hungarian verbs: mood, tense, and modality. ${ }^{2}$ His most relevant findings can be summarized like this:

- In a handful of cases we find variable scope order among these inflectional categories, accompanied by rigidly fixed affix order on the verb forms. In particular: a $\mathrm{V}+\mathrm{Mod}+\mathrm{T}$ sequence can be paired with either scope order of $\mathrm{T}$ and Mod, though with Mod receiving different interpretations: (1a); a V+Mod+Mood sequence can either be understood as a $\mathrm{M}>$ Mod scope order, or as bouletic modality, co-marked, so to say, by modality and mood morphology: (1b); a $\mathrm{V}+\mathrm{T}\left(+\mathrm{V}_{\text {expl }}\right)+\mathrm{M}$ sequence can either place tense in the scope of mood, or induce a reading where tense scopes over some modality of volition, whose only indicator is the conditional marker: (1c);

${ }^{1}$ See Antal (1961) for more on this, and Rebrus (2000) and Bartos (2003) for recent theoretical accounts.

${ }^{2}$ In Hungarian, the only overt modality marker is $-h A t$, standing for various flavors of potentiality/possibility; tense can be overt past $(-t(t))$, or unmarked non-past; mood is either conditional $(-n A)$, or subjunctive $(-j)$, or unmarked indicative. 
finally, a form where all three categories are overtly marked (i.e., possibility+past+conditional) has a primary reading with straight scope order $(\mathrm{M}>\mathrm{T}>\mathrm{Mod})$, but with a secondary reading as well, where M and Mod co-mark bouletic modality again, and standing in either scope order with respect to $\mathrm{T}$ (i.e., there is three-way ambiguity here): (1d).

(1) (a) Vár-hat-t-ak. ${ }^{3}$

wait-poss-past-3pl

'They could/were allowed to wait.'

or: 'They may have waited'

$\mathrm{T}>\operatorname{Mod}_{\text {deontic }}$

(b) Vár-hat-ná-nak.

wait-poss-cond-3pl

'They could (possibly) wait.'

$\operatorname{Mod}_{\text {epistemic }}>\mathrm{T}$

or: 'They really should wait.'

$\mathrm{M}>\operatorname{Mod}_{\text {deontic }}$

$\mathrm{M}+\operatorname{Mod}=$ Mod $_{\text {bouletic }}$

(c) Vár-t-ak vol-na. ${ }^{4}$

wait-past-3pl expl-cond

'They would have waited.'

or: 'They fancied waiting.'

$\mathrm{M}>\mathrm{T}$

$\mathrm{T}>\operatorname{Mod}_{\text {volition }}$

(d) Vár-hat-t-ak vol-na.

wait-poss-past-3pl expl-cond

'They could have waited.'

or: 'They should have waited.'

$$
\begin{aligned}
& \mathrm{M}>\mathrm{T}>\operatorname{Mod}_{\text {deontic }} \\
& \mathrm{M}+\operatorname{Mod}=\text { Mod }_{\text {bouletic }}<>\mathrm{T}
\end{aligned}
$$

- These facts pose a problem to standard assumptions about matchings between syntax and morphology, and syntax and semantics (such as the Mirror Principle (Baker 1985), by which we take the syntactic order of the inflectional categories in question to be the mirror image of their morphological order on the verb forms; the syntax of scope (e.g., Aoun-Li 1993); and the hypothesis of a rigid/universal hierarchy of functional projections (most sharply put by Cinque 1999).

- Mood and modality (at least on the level of morphological marking) appear very closely related, sometimes cooperating in marking certain modalities or scope orders.

3 The following abbreviations are used in the glosses, beside standard ones: cond $=$ conditional mood, expl = expletive $\mathrm{V}$-stem, poss $=$ possibility modality, $\mathrm{pv}=$ preverb, def $=$ definite object agreement, ps $=$ possessor.

${ }^{4}$ For an account of the obligatory use of an expletive V-stem (vol-) here see Bartos (2003, 40-2). 
Eszes (2004) challenges some of these observations from a semantic point of view - he claims that conditional mood marking is not confined to conditional contexts, ${ }^{5}$ and in some cases it actually signals counterfactuality (or counterfactual scope relations):

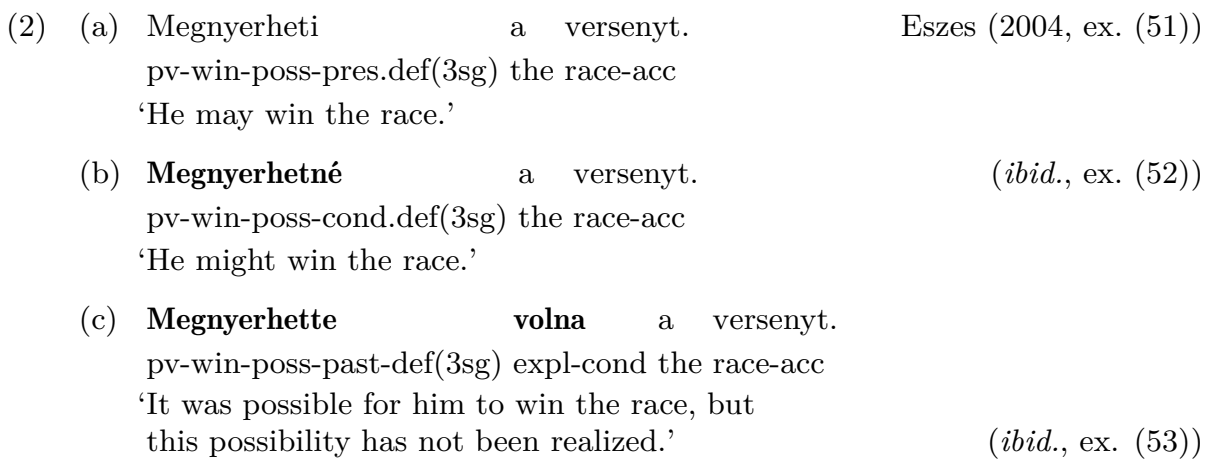

He argues that $(2 \mathrm{~b})$ simply pushes the modality expressed in $(2 \mathrm{a})$ to a more distant, less likely degree, i.e., the $(2 \mathrm{a}) \sim(2 \mathrm{~b})$ difference is much like the may might difference in English (as analysed by Condoravdi 2001). And in (2c), the role of the mood marking is to signal a forced scope inversion between Mod and T, to T > Mod ('PERF > MOD' in Eszes' terminology), to the effect of expressing counterfactuality.

My goal, therefore, is to propose an account of (i) the semantic contribution of conditional mood, and of (ii) the close interrelatedness of conditional mood and the modalities expressed by the affix - $h A t$, which captures both the M-Mod scope and co-marking effects observed by Bartos (2003), and Eszes' insight on the relation between conditional mood and counterfactuality.

\subsection{The various modalities represented by $-h A t$}

Before we can proceed with our task, let us survey the various modality types expressed by the affix - $h A t$ in Hungarian. (3a-e) are the relevant types from Kiefer $(1981 ; 1985 ; 2005)$, while $(3 \mathrm{f}-\mathrm{g})$ illustrate the distinction drawn between narrow and wide epistemic possibility by Farkas

\footnotetext{
${ }^{5}$ In fact, when it appears in a conditional context, it must be correlated by another conditional marker in the other clause (antecedent or consequent).
} 
(1992), following Karttunen (1972). Finally, recall that (2c) above is an example of metaphysical modality from Eszes (2004).

(3) (a) Holnap eshet az eső.

OBJECTIVE EPISTEMIC tomorrow fall-poss(3sg) the rain

'In view of our knowledge about the world, it is possible that it'll rain tomorrow.'

(b) Péter most az iskolában lehet.

SUBJECTIVE EPISTEMIC

P. now the school-in be-poss(3sg)

'In view of our knowledge and beliefs about the world, it is quite likely that Peter is in school now.'

(c) Itt parkolhatsz.

DEONTIC here park-poss-2sg

'In view of the relevant regulations and norms, you are allowed to park here.'

(d) Innen mindenki láthatja a tűzijátékot. CIRCUMSTANTIAL from.here everyone see-poss-def(3sg) the fireworks-acc

'In view of the circumstances of spacetime, it is possible for everyone to see the fireworks from here.'

(e) Igazán várhatnál egy kicsit.

BOULETIC

really wait-poss-cond-2sg a little-acc

'Fancy you could wait a little / I'd like you to wait a little.'

(f) Az orvos már megérkezhetett. the doctor already pv-arrive-poss-past(3sg)

'It is compatible with our knowledge that the doctor has arrived already.'

(g) Szép idő van, de eshetne az eső. WIDE EPISTEMIC nice weather is but fall-poss-cond(3sg) the rain (ibid., (28))

'There are some worlds compatible with our knowledge, in which (unlike in our actual world) it is raining.'

Note that the wide epistemic and metaphysical modalities always involve non-indicative mood, and also that they are quite close to each other in many respects. Moreover, Kiefer's subjective and objective epistemic modalities are subcases of Farkas's narrow epistemic type. 


\subsection{The distribution of conditional mood}

In this subsection, some data are presented (partly following the presentation in Kálmán 2001, 166-8) to illustrate that while in many cases conditional mood is (or appears to be) formally selected by some superordinate lexical item, there are various unselected occurrences, as well, so these must be covered by the analysis I wish to propose afterwards.

\subsubsection{Conditional mood selected by a higher predicate}

The basic cases of conditional mood selection are the following:

- by certain inherently negative predicates (conditional mood optional): (4a);

- some factive verbs under negation, with their factivity canceled (conditional mood optional): (4b);

- non-factives expressing informational uncertainty under negation (conditional mood optional): (4c);

- by various negative items, e.g., negative postpositions (helyett 'instead.of', nélkül 'without') (conditional mood obligatory with ahelyett, optional with anélkül): (4d);

- in relative clauses modifying negative quantifiers (conditional mood optional): (4e).

(4) (a) Kétlem/Valószínűtlen/Lehetetlen, hogy Maci Laci elég okos lenne. doubt-1sg/unlikely/impossible that Yogi Bear enough smart be-cond(3sg) 'I doubt/It's unlikely/impossible that Yogi Bear is smart enough.'

(b) Nem emlékeztek rá/ bizonyították/látszott, hogy not remember-past-3pl it.sublat/ prove-past-def-3pl/seem-past(3sg) that Maci Laci elég okos lenne.

Yogi Bear enough smart be-cond(3sg)

'They didn't recall/prove that Y.B. was smart enough./It didn't look like Yogi Bear was smart enough.'

(c) Nem valószínű/feltételezzük/tartunk attól, hogy Maci Laci túl okos lenne. not likely/suppose-1pl/keep-1pl it-from that Yogi Bear too smart be-cond(3sg) 'It is not likely/We don't suppose/We are not afraid that Yogi Bear is too smart.'

(d) ... ahelyett/anélkül, hogy aludt volna that-instead.of/that-without that sleep-past(3sg) expl-cond 'instead of / without (him/her) sleeping'

(e) [Nem kérek tőled] semmi (olyat), ami nehéz lenne. not ask(pres)1sg from.you nothing such-acc what difficult be-cond(3sg) '[I'm asking you for] nothing that would be difficult.' 
While it is certainly possible that these constructions are reasonably analysed via (optional or obligatory) selection for the feature COND by the relevant superordinate items, in the light of the subsequent examples and discussion we will want to reconsider the issue in section $\mathbf{3}$.

\subsubsection{Unselected conditional mood}

We most frequently find unselected occurrences of conditional marking in

- irrealis conditionals (both in the antecedent and in the consequent): $(5 \mathrm{a}, \mathrm{b})$;

- in wishes: (5c, d);

- indicating counterfactuality with certain modalities (metaphysical, wide epistemic; cf. section $\mathbf{2 . 2}$ above): (5e);

- marking bouletic or volitional modality: seen in $((1 \mathrm{~b}, \mathrm{~d}),(2 \mathrm{e}))$ and (1d), above, respectively.

(5) (a) Ha esne az eső, hazaindulnánk.

if fall-cond(3sg) the rain home-start-cond-1pl

'If it rained, we'd be heading for home.'

(b) Ha esett volna az eső, hazaindultunk volna.

if fall-past expl-cond the rain home-start-past-1pl expl-cond

'If it had rained, we would have been heading for home.'

(c) Bárcsak havazna!

if.only snow-cond $(3 \mathrm{sg})$

'If only it snowed!'

(d) Hogy rohadna el!

that rot-cond(3sg) away

'Damn!' [lit.: '(Wish) it would rot!]

(e) Szerintem Maci Laci megnyerte volna ezt a versenyt. according.to-1sg Yogi Bear pv-win-past(3sg) expl-cond this-acc the race-acc 'I think Y. B. would have won this race [had it not been for some circumstance that rendered it otherwise].'

Furthermore, it is interesting to note that in earlier stages of Hungarian, the conditional mood was used in subjunctive-like function in subordinate clauses of purpose and time: 
(6) (a) \% "Szintén immár lóra ugrani akara,

also now horse-onto jump-inf want-past.3sg

Hogy Arszlán táborához elszaladhatna" 6

that Arslan camp-3sg.ps-to away-run-poss-cond(3sg)

'Also now he wanted to jump on a horse // so that he could run to Arslan's camp.'

(b) \% [Egy nyavalyás kicsiny bárány budosóba esék.] Melyet mikoron

a wretched little lamb hiding-into fall-past.3sg which-acc when

az farkas megtalált volna, nem akará mindjárást megenni [... $]^{7}$

the wolf pv-find-perf expl-cond not want-past.3sg at.once pv-eat-inf

'[A wretched little lamb went into hiding.] When the wolf found her, he didn't want to eat her immediately.'

While not directly relevant to our account, these historical data are nevertheless suggestive of our analysis being on the right track, as will be seen presently.

\section{The semantic contribution of conditional morphology}

Let us now take a look at what we find in the literature on the ways of expressing counterfactuality $(\mathrm{CF})$. The most directly useful piece is Iatridou (2000), where the emergence of CF (as in wishes and non-realizing conditionals) is attributed to a morphosyntactic feature $\operatorname{excl}(F)$, where $F$ ranges over times $t$ and worlds $w$ : temporal or modal exclusion ("The utterance time/world is excluded from the topic time/world"). The former, $\operatorname{excl}(t)$, is interpreted as tense, i.e., time relations, the latter yields modal relations, and is a key ingredient of $\mathrm{CF}$ - in fact, the meaning of a $\mathrm{CF}$ conditional is none else than the meaning of the corresponding non-CF conditional plus the statement "the topic worlds exclude the actual world" (op.cit., 245-7). And a general picture that emerges from a cross-linguistic survey is that most often, what encodes CF is the same as what encodes $\operatorname{excl}(t)$, e.g., tense morphology — as is the case in English:

(7) (a) If Vic invited me, I would go.

(b) If Vic had invited me, I would have gone.

(c) I wish Vic (had) invited me.

${ }^{6}$ Szigeti veszedelem II/14. [The peril of Sziget, ch. 2, verse 14], by Miklós Zrínyi (17th c.).

${ }^{7}$ Az farkasról és bárányról [Of the wolf and lamb], by Gábor Pesti (16th c.) — cited from É. Kiss (2004), and the glosses reflect her analysis in certain respects. 
(7a) contains "fake past": it is a statement holding at the time of utterance, so $\operatorname{excl}(F)$ is not $\operatorname{excl}(t)$, but $\operatorname{excl}(w)$, though, of course, in many other instances past (or, to put it more aptly: excl) morphology gets interpreted as $\operatorname{excl}(t)$. The antecedent of $(7 \mathrm{~b})$ contains two "layers" of $\operatorname{excl}(F)$, one for $t$, and another for $w$, hence the use of the past perfect. $\mathrm{CF}$ wishes, as (7c), show a similar effect.

In languages which appear to encode $\operatorname{excl}(F)$ with subjunctive mood, it is always the past subjunctive that is used, i.e., the encoder is, again, some special past tense. 'Conditional mood' as such does not exist, Iatridou claims: what is labeled as 'conditional' (e.g., in French) is actually indicative mood augmented with special tense/aspect. In Hungarian, however, there is little reason to think so ${ }^{8}$ in my opinion, so at this point I diverge from Iatridou's argumentation.

With this reservation, let us check the Hungarian data. Obviously, in all the relevant Hungarian examples (cf. (5)), we find conditional mood marking, in wishes, as well as in both clauses of conditionals, while the tense marking simply serves to locate the event/proposition in time, past serving the $\operatorname{excl}(t)$ purpose. From a functional perspective it is therefore straightforward to conclude that Hungarian conditional marking plays the same role of indicating $\mathrm{CF}$ as past morphology in English, and many other languages. But what is even more significant is that if we look at the 'selected' instances of conditional mood in (3), we find that they, too, appear in counterfactual contexts, or at least non-factual contexts where the possibility of the realization of the event is very slight (cf. the cases of "future less vivid" in Iatridou (2000), which share the counterfactual morphology in various languages). The only quirk is the optionality of conditional morphology here, but even this falls in place at least as well as in a selection-based analysis: if it is meant to signal CF, then it is somewhat redundant, insofar as the matrix domain makes it clear that the embedded proposition is CF, i.e., $\operatorname{excl}(w)$-marking on the embedded predicate is reinforcement, rather than primary clue. In a selectional analysis, on the other hand, optionality is but a diacritic on the selectional feature. There is one potentially worrisome circumstance though: in some cases the optional conditional mood alternates with the indicative, while in others, the subjunctive:

\footnotetext{
${ }^{8}$ See the Appendix, though, for some speculation on this point.
} 
(4) (a') Kétlem, hogy Maci Laci elég okos. doubt-1sg that Yogi Bear enough smart 'I doubt that Yogi Bear is smart enough.'

$\left(a^{\prime \prime}\right)$ Valószínütlen/Lehetetlen, hogy Maci Laci elég okos legyen. unlikely/impossible that Yogi Bear enough smart be-subj.3sg 'It's unlikely/impossible that Yogi Bear is smart enough. SUBJUNCTIVE

The (4b, c)-types go with the indicative, alternatively. (4d, e) are only slightly different: in past tense, conditional morphology is obligatory, while it alternates freely with the indicative in the present.

A thorough treatment of mood choice in these constructions would go beyond the scope of the present paper, but following the lead ofFarkas (1992), Rákosi (2001), and Tóth (2006), we must suppose that the modal semantics of the matrix determines the choice: the less compatible the topic world of the embedded proposition with the real world of the utterance, the less realis the mood - indicative being more realis than subjunctive, which, in turn, is more realis than the conditional. In the Kratzerian parlance of Tóth, the more remote the worlds in which the embedded proposition hold from the actual world, the less realistic the modal base, and the less realis the mood.

Coming back now to our main concern: recall Eszes' (2004) proposal: in the metaphysical modality cases (e.g., (2c)), the conditional morphology serves to indicate "CF scope order" between Mod and T ( $\mathrm{T}>\mathrm{Mod}$ ). This, again, ties in with the above-made observation about the role of conditional mood marking: in Hungarian, the marker of $\operatorname{excl}(w)$, i.e., of counterfactuality, is obviously none else than conditional mood morphology. Furthermore, this observation paired with the one about "fake" conditional mood expressing some sort of modality (volition-disposition as in (1c)), or combining with Mod-marking to express some other sort of modality (bouletic, as in $(1 \mathrm{~b}, \mathrm{~d})$ ) leads us to investigating the formal morphosyntactic relation between Mood (M) and Modality (Mod) in Hungarian, as laid out in the next section.

\section{Conditional mood and modal possibility - An AGREE relation}

Summarizing the relevant content of the data sections above, we have identified the following cooccurrence facts between COND and POss: 
(8) (a) Modalities cooccurring with conditional mood:

- wide epistemic

- metaphysical

- volitional-dispositional (with semantically apparently empty $\mathrm{M}_{\text {cond }}$ )

- bouletic

(b) Modality cooccurring with indicative mood:

- narrow epistemic

(c) Modalities cooccurring with any mood:

- deontic

- circumstantial

I assume with Bartos (2003), in keeping with the Mirror Principle and the syntactic representation of scope relations, the following projectional hierarchy: [ M [ T [ Mod [...] ]]]. ${ }^{9}$ Under standard assumptions, this means that $\mathrm{M}$ and Mod cannot select one another, since they are not in the local relationship necessary for that kind of relation, because of the intervening $\mathrm{T}$. We thus conclude that these cooccurrences are best accounted for in terms of an AGREE relation, in a Chomsky (2001)-type syntactic framework. In particular, as regards the system of the relevant formal features, let us adopt Kratzer's $(1981 ; 1991)$ theory of modality, with the following feature breakdown:

(9) modal force

$$
\begin{aligned}
& \rightarrow[ \pm \text { poss }]+\text { poss } \rightarrow \text { ep, deont, circ, boul, } \ldots{ }^{10} \\
& - \text { poss } \rightarrow \text { vol } \\
& \text { modal base } \quad \rightarrow[ \pm \mathrm{ep}] \quad+\mathrm{ep} \rightarrow \mathrm{ep} \\
& - \text { ep } \rightarrow \text { deont, circ, boul, metaph, ... } \\
& \text { modal exclusion }(\operatorname{excl}(w)) \rightarrow[ \pm \text { excl }] \quad+\operatorname{excl} \rightarrow \text { vol, metaph, w-ep, } \ldots \\
& \text { - excl } \rightarrow \text { n-ep, circ, deont, ... }
\end{aligned}
$$$$
\text { ordering source } \quad \rightarrow[x \text { src }] \quad x=\{\text { deont, boul, stereotypical, } \ldots\}
$$

That is, we have the three main ingredients of Kratzer's theory: modal force, modal base, and ordering source, represented by one formal feature each: possibility, epistemicity, and source, respectively. The various

${ }^{9}$ For detailed arguments, and for an account of why/how the expletive V-stem volappears when $\mathrm{T}=$ past and $\mathrm{M}=$ cond, see Bartos $(1999 ; 2003)$.

10 The abbreviations: ep $=$ epistemic, circ $=$ circumstantial, deont $=$ deontic, boul $=$ bouletic, vol $=$ volitional, metaph $=$ metaphysical, $\mathrm{n}$-ep $=$ narrow epistemic, $\mathrm{w}-\mathrm{ep}=$ wide epistemic. 
available values (binary for the former two, and multiple for the last one) characterize the different modalities as shown in (9). This system is completed by the addition of the modal exclusion feature, as an instantiation of the more general $\operatorname{excl}(F)$. In sum: these features define the various modalities of the category Mod, and relate it to the category $\mathrm{M}$ via the AGREE relation. The key element in capturing the cooccurrence effects is $[ \pm$ excl]. In this respect, narrow epistemic, circumstantial, and deontic modalities display no modal exclusion/distancing: the proposition in their case is potentially valid in the actual world. The other types, on the other hand, do involve such distancing, hence the specification [+ excl], so they can be characterized as CF, in Iatridou's sense, whereby conditional morphology will possibly (co)occur with them.

The most interesting point in (9) is the split between narrow and wide epistemic modality with respect to the [excl] feature, and this split follows from a distinction within the epistemic modal base: if the modal base is totally realistic (in Kratzer's (1981) sense), i.e., the real world is inside the set of worlds in which the proposition is claimed to be realized, as is the case for narrow epistemics, the feature is specified for non-exclusion, while if the modal base is only partially realistic, i.e., the real world is not necessarily in the anchor set, as in the case of wide epistemics (Farkas 1992), [+ excl] is the appropriate specification.

The concrete mechanism is the following: $M$ may either have an independently specified [excl] feature (e.g., when so selected by some higher head, such as $\mathrm{C}$ in conditional clauses, or by some covert item ('I wish ...'), as in wishes), or it may inherit the value by agreeing with Mod. $[+$ excl $]$ is then spelled out as conditional mood marking, and [- excl] as indicative mood marking. In the following subsections we will see how this works in the various cases.

\subsection{Conditional marking, no $-h A t$}

\subsubsection{Wishes and conditionals}

On one hand, it is tempting to assume that wishes contain an overt or covert embedding speech-act predicate ('I wish ...'), and/or a particular Force $^{0}$ (bárcsak, as in (5c) above), which exert selection for a [+ excl] feature on $\mathrm{M}$. That is, in the case of wishes the emergence of conditional morphology could then be put down to pure formal feature selection. However, it is quite clear that (i) these sentences are paradigmatic cases 
of self-contained counterfactuality, i.e., they can easily be analysed with their $\mathrm{M}$ lexically specified as $[+$ excl], directly towards a CF interpretation; and that (ii) a hypothetical matrix predicate with the 'I wish' meaning in Hungarian, such as azt kívánom ... 'I wish...' or (azt) szeretném 'I would like [it to be the case] that ...', when overtly expressed, selects for the subjunctive either obligatorily (as the former), or optionally, besides the conditional (as the latter), unless bárcsak is inserted, which guarantees the conditional morphology:

(10) (a) Azt kívánom, hogy álljon el az eső. it-acc wish-(pres) 1 sg that stop-subj-3sg pv the rain 'I wish it stopped raining./I want for it to stop raining.'

$\left(a^{\prime}\right)$ Azt kívánom, hogy bárcsak elállna az eső. it-acc wish-(pres) 1 sg that if.only pv-stop-cond(3sg) the rain 'I wish it stopped raining./ I want for it to stop raining.'

(b) Szeretném, hogy elálljon az eső. like-cond-def-1sg that pv-stop-subj-3sg the rain 'I want it to stop raining.'

(c) Szeretném, ha elállna az eső. like-cond-def-1sg if pv-stop-cond(3sg) the rain 'I'd like it to be the case that it stops raining.'

That is, it is neither necessary nor adequate to appeal to formal selection - we must take the conditional in non-overtly-embedded wishes as an independently motivated denoter of CF. (Further arguments against attributing the $\mathrm{CF}$ nature of wishes to a hypothesized, covert matrix predicate is found in Iatridou $(2000,243)$.)

In conditionals, CF may affect the antecedent (it provides a condition that holds in worlds incompatible with what is the case in, or what is known of, the actual world) - thus conditional mood as the $\operatorname{excl}(w)$ marker in such clauses occurs in its own right, again, with the semantic consequence of $\mathrm{CF}$ interpretation. As regards the consequents of conditionals, they most probably match the antecedent in Excl-marking, ${ }^{11}$

${ }^{11}$ Iatridou $(2000,268)$ hints that this may be via some sort of agreement relation between the two clauses, but notes, qutoing Cho (1997), that there are languages where only the antecedents are marked for $\mathrm{CF}$, but not the consequents, 
but often have a futurity component, ${ }^{12}$ too, and the same CF morphology often appears on the 'wish' matrix verb of CF wishes if it is overtin Hungarian the interclausal matching holds, and at least one 'wish' V (szeretné, $h a \ldots$ '. (s)he would like it if ...') does bear CF-morphology, but there is no sign of futurity whatsoever.

\subsubsection{Other allegedly selected cases of conditional mood}

In the examples of (4) above, what embeds the clauses marked for conditional mood are contexts which negatively evaluate the (probability of the) truth of the embedded proposition: inherent negatives, negated factives, etc. As pointed out by Farkas $(1992,220)$, in such contexts, mood choice of the embedded clause depends on the modal distance of the topic world from the actual world (i.e., how realistic the modal base is). Augmenting her basic distinction between indicative and subjunctive by adding the conditional as an 'in between' case, we arrive at the following realizations:

- very close or identical worlds / totally realistic modal base $\rightarrow$ indicative

- more remote worlds / partially realistic modal base $\rightarrow$ conditional

- remotest worlds / incompatibility with what is known of the real world $\rightarrow$ subjunctive

As seen in the examples, too, negated categorical epistemic predicates favor the subjunctive, while non-categorically evaluative ones settle for the conditional - in this respect, both conditional and subjunctive indicate counterfactuality.

The conclusion is that in these cases we need not (and in fact, should not) posit mood selection by a matrix head; instead: semantic compatibility is the decisive factor in determining mood marking in the embedded domain.

\subsubsection{Volition/disposition}

This is a true instance of specifying the value of $\mathrm{M}$ via agreement with Mod. The details are these: Mod bears the features [- poss, + excl]

i.e., marking on the consequent is not universally necessary. Hungarian displays agreement/matching between the clauses, though.

${ }^{12}$ In fact, Iatridou (2000) claims that the so-called conditional mood in many languages (e.g., French) is really a compound of an Excl-marker and a future-marker. 
the spellout of which is $\emptyset$ (zero morphology), and the interpretation it is assigned is volition or disposition, cf. (1c) in section 2.1. M, on the other hand, bears an unvalued feature [ $u$ excl:], which must be valued through an AGREE relation with the relevant feature on Mod: [excl: +$]$. Once $\mathrm{M}$ has this feature valued as ' + ', it will be spelled out as the suffix $-n A$ (and the $\mathrm{CF}$ in interpretation concomitantly obtains). Note, though, that some archaic and dialectal forms (11a), and an idiomatic nominalizational pattern (11b), still retain overt $-h A t$ for this kind of modality, while the productive pattern displays the zero marking:

(11) (a) ${ }^{\%}$ Alhatnék/Alhatnám.

sleep-poss-cond-1sg

'I'd like to sleep.'

(b) Alhatnékja van.

sleep-poss-cond-1sg-3sg.ps be-pres.3sg

'He'd like to sleep.' [lit.: 'He has sleep-wish.']

\subsection{Conditional mood in cooccurrence with $-h A t$}

\subsubsection{Deontic and circumstantial modalities}

In these cases Mod is [- excl] (see (9)), so unless M is marked otherwise (i.e., unless it is $\mathrm{CF}$ by some other means), it gets its relevant feature valued as in the AGREE relation with Mod [- excl], yielding indicative mood morphology on the spellout side.

\subsubsection{Narrow epistemic modality}

Let us now turn to the more complicated case of epistemic modality. Here we are immediately faced with a distinction between narrow and wide epistemic modality, in the parlance of Farkas (1992). There appear to be two hallmarks of narrow epistemic modality: (i) it only occurs with indicative/unmarked mood, and (ii) it takes scope over tense (see (1a), (3f) above).

Concerning (i), we might choose to follow Farkas' solution of semantic compatibility (op.cit., 220), but this alone would not yield (ii). Let us therefore see if there is any explanation covering both (i) and (ii). As regards the scope order, we seem to have two options (in the wake of the discussion in Bartos 2003). Either (a) we posit a category $\operatorname{Mod}_{n-e p}$ in a position c-commanding $\mathrm{T}$ in syntax, as distinct from other instantiations 
of the category Mod below T, but then we lose any straightforward account of the single identical affix order corresponding to both, or (b) we argue that the scope effect is only apparent. Bartos (2003) chose the former option, and was forced into a not particularly explanatory analysis of the scope switch. Here we, on the other hand, opt for devising a treatment in the latter vein. Let us assume that (against all appearances) the morphologically unmarked $\mathrm{M}$ in this case is not indicative but evidential (cf. a similar suggestion for German in Drubig 2001, pointing back to ideas presented by Westmoreland 1995). M can thus be specified for an [evid] feature, the value of which matches the value of Mod's [ep]-feature, i.e., $\mathrm{M}$ will be specified as $[-$ excl, + evid $],{ }^{13}$ which is realized as $\emptyset$, and interpreted as 'in view of our experience/perception of facts of the world it is possible that $p$ '. In essence, therefore, what scopes over $\mathrm{T}$ is not Mod itself, but $\mathrm{M}_{\text {evid }}$, which is morphologically homonymic with $\mathrm{M}_{\text {ind }}$, but constitutes a separate mood. While it would be rather difficult to find any direct, surface evidence for such a mood distinction in Hungarian, the scope "reversal" effect attested in (1a) can be seen as covert, secondary indication of the validity of this distinction, nevertheless.

\subsubsection{Wide epistemic modality}

Next, we must tackle the wide epistemic modality type. Unlike narrow epistemic modality, it (i) cooccurs with $\mathrm{M}_{\text {cond }}$, and (ii) scopes below $\mathrm{T}$. Since such Mod has the values [+ poss, + ep, + excl], $M$ will get valued as $[+$ excl] via AGREE, yielding the spellout $-n A$. Mod has no access to any position scoping over $\mathrm{T}$, and $\mathrm{M}$ is not evidential in this case: we are not considering our experience or perception of facts of any world, but flash up hypothetical possibilities pertaining to "worlds that are not compatible with what is known about the actual world" (Farkas 1992, 220). ${ }^{14}$ The absence of "inverse scope" effects between Mod and T thus follows, too.

\subsubsection{Metaphysical possibility}

The final case that needs to be considered is metaphysical possibility. Mod in this case is specified as $[+$ excl, + poss], but [-ep] (the modal

${ }^{13}$ Whether $\mathrm{M}$ is [- excl] by virtue of its own [+ evid] feature, or it is valued that way by Mod is immaterial at the moment.

${ }^{14}$ Note that Farkas explicitly labels wide epistemic possibility as CF, which ties in with the crucial insight of the present analysis: $\mathrm{CF}$ is the interpretation of [+excl] on $\mathrm{M}$. 
base is non-epistemic), therefore it will value $\mathrm{M}$ with $[+$ excl], resulting in conditional morphology and CF interpretation, just as expected. Disregarding the epistemicity difference, this modality behaves analoguously to wide epistemic possibility, as far as its relation to mood is concerned.

To sum up the results of this section: the various occurrences of conditional morphology have been shown to be the reflex of the feature $[+\mathrm{excl}]$ on the category $\mathrm{M}$ in the structure, which is either due to some independent factor (selected/forced CF interpretation by the matrix context), or conferred on M in an AGREE relation with Mod, which may bear this feature by lexical specification. ${ }^{15}$

\section{Why not T?}

In this final section, we seek the answer to the question of why it is M, rather than $\mathrm{T}$, that assumes the role of encoding $\mathrm{CF}$ in Hungarian, unlike in many languages, including English, where CF is an alternative interpretation of what is usually termed 'past tense' (Iatridou 2000). Given that it is this "fake" $\mathrm{T}$ that is the most (proto-?)typical encoder of $\operatorname{excl}(x)$, why does Hungarian opt for using conditional mood to this end?

There seem to be two available answers to this question.

- Answer 1: Because tense and mood are "faces of the same coin", in the sense of Antal (1961), so they are functionally equivalent, and because $\mathrm{M}$ is higher in the clause structure than $\mathrm{T}, \mathrm{CF}$ is marked on M. However, the argument about the identity of mood and tense is narrowly morphological, and does not hold at the level of syntax. While it is certainly true that (i) the subjunctive is tenseless, that (ii) the unmarked "combination" of nonpast tense and indicative mood is plausibly seen as a single zero, instead of two zero items in a sequence, and that (iii) simultaneous past tense and conditional mood can only be expressed by resorting to a complex V-form (cf. (1c), and the discussion in Bartos 2003), the possibility of syntactic and semantic cooccurrence of past and conditional takes away most of the motivation for this answer - it is precisely these two that are

${ }^{15}$ It is not hopeless to actually derive the value of [excl] on Mod from the other modal specifications, but whether this is the correct view remains to be explored by future research. Here I take this feature to be lexically valued on Mod, for the time being. 
the candidates for marking $\mathrm{CF}$, so if they can cooccur, it is not clear why one would be more suitable for this task than the other.

- Answer 2: Because morphological tense is not deictic tense in Hungarian, but relative tense (or aspect), which is less appropriate for expressing the notion of exclusion. The arguments for the non-deictic nature of tense in Hungarian are the following:

- $\mathrm{T}$ is not deictic, but relative: there is no direct matching with real-world temporality (12a, b), and no sequence of tenses effect in this language $(12 \mathrm{c})$ :

(12) (a) Holnap ilyenkorra már átléptuik az Egyenlítőt. tomorrow by.this.time already over-step-past-1pl the Equator-acc 'By this time tomorrow, we will already have crossed the Equator.'

(b) Eredetileg úgy volt, hogy már tegnap elindulok, originally so was that already yesterday away-start-pres.1sg és akkor holnapra már ott is lettem volna. and then by.tomorrow already there too be-past-1sg expl-cond 'Originally, I was supposed to leave yesterday, and then I would have been there by tomorrow.'

(c) Péter azt mondta / rájött, P. it-acc say-past.3sg / realize-past.3sg [hogy Mari alszik/aludt]. that M. sleep-pres(3sg)/sleep-past(3sg) 'Peter said / realized that Mary was/had been asleep.'

- Temporal adverbials do not formally agree with $\mathrm{T}$; this is shown by the fact that they cannot locally license any T-switch in ellipsis under agreement (13a), the way subjects can do so with respect to Agr-marking (13b) (Bartos 2000):

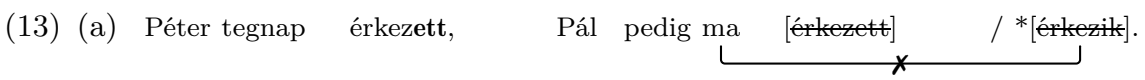

P. yesterday arrive-past(3sg) Paul and today arrive-past(3sg)/ arrive-pres(3sg) 'Peter arrived yesterday, and Paul [arrived / *is arriving] today.'

(b) Tegnap Péter érkezett meg, ma pedig én [érkeztem]. yesterday P. arrive-past(3sg) pv today and I arrive-past-1sg 'Yesterday Peter arrived, while today I did.' 
- As É. Kiss (2004; 2005) argued, what is regarded as tensemorphology in present-day Hungarian was originally an aspect marker (perfective), and has been reanalysed in the course of language change - but an alternative interpretation of historical facts, more consistent with the above two observations, is that tense-morphology is still rather like aspect marking: T-anterior vs. T-concurrent.

- Regarding "past tense" morphology as perfectivity marking is also in line with Eszes' (2004) analysis: he follows Condoravdi's (2001) ideas in analysing 'past' as 'perfective' in Hungarian.

In sum: tense in Hungarian is not well-suited for marking $\operatorname{excl}(x)$, hence this language resorts to the use of a particular mood to express $\operatorname{excl}(w)$ instead of $\mathrm{T}$.

\section{Conclusion}

I have argued that conditional mood morphology in Hungarian is a reflex (spellout) of the feature $\operatorname{excl}(w)$, the semantic interpretation of which is counterfactuality. In certain cases (such as non-overtly-embedded wishes, or the antecedents of CF conditionals) this feature is lexically specified on $\mathrm{M}$, with the direct interpretive aim of counterfactuality, while in others $M$ has this feature unvalued, and inherits its value from the category Mod in a standard AGREE relation. The relevant feature of Mod, in turn, is possibly a derivative of its Kratzerian modality feature configuration, albeit this idea has not been pursued here. Finally, I have shown that, unlike what is found in many other languages, Hungarian cannot use tense marking as the exponent of $\operatorname{excl}(w)$, because its "tense" is relative, rather than deictic, i.e., it is rather aspect-like, so it is incapable of expressing exclusion (even $\operatorname{excl}(t)$, let alone $\operatorname{excl}(w))$. Therefore this language makes use of mood morphology to encode $\mathrm{CF}$, in the particular form of conditional mood.

\section{Appendix}

There is an alternative morphosyntactic account of excl-marking in Hungarian, which is more consistent with Iatridou's (2000) views. Following 
É. Kiss $(2004 ; 2005)$, and Iatridou (2000), one might speculate that conditional mood is morphologically complex in Hungarian: the affix $-n A$ is segmentable into $-n$ - and $-A$, the former being the mood affix proper, and the latter being none else than the now "extinct", archaic "narrative" past affix (cf. the forms akara, esék, akará in (6a,b) above):

(14) olvas-n-a cf. olvas-a

read-cond-past read-past

This way we would have an explanation for why "conditional mood" is used for encoding $\operatorname{excl}(w)$. But there is precious little independent motivation for synchronically identifying the final $-A$ as past tense, since this past tense is no longer in use in modern Hungarian, except, possibly, for this particular case in question. So there is practically no evidence available to the child at the time of language acquisition for having to segment the conditional marker as 'cond + past'. (NB. Such a segmentation account would have repercussions for the analysis of the syntax of inflection in Bartos (2003), as well, since this would then constitute motivation for assuming a $\left[\mathrm{T}_{\text {past }}\left[\mathrm{M}_{\text {cond }}\right]\right]$ hierarchy, rather than the other way round, making the case of dummy vol- insertion even more quirkythis case would then fall under some morphological constraint banning double tense-marking on a single $\mathrm{V}$, most probably.) For this reason, I see no point in pursuing this idea any further.

\section{References}

Antal, László 1961. Gondolatok a magyar igéről [Thoughts on the Hungarian verb]. In: Magyar Nyelv $57: 273-79$.

Aoun, Joseph - Yen-hui Audrey Li 1993. Syntax of scope. MIT Press, Cambridge MA.

Baker, Mark 1985. The Mirror Principle and morphosyntactic explanation. In: Linguistic Inquiry $16: 373-415$.

Bartos, Huba 1999. Morfoszintaxis és interpretáció: a magyar inflexiós jelenségek szintaktikai háttere [Morphosyntax and interpretation: The syntactic background of Hungarian inflectional phenomena]. Doctoral dissertation, Eötvös Loránd University (ELTE), Budapest.

Bartos, Huba 2000. VP-ellipsis and verbal inflection in Hungarian. In: Acta Linguistica Hungarica $47: 3-23$.

Bartos, Huba 2003. On-line morphology: The morphosyntax of Hungarian verbal inflection. In: Uwe Jughanns - Luka Szucsich (eds): Syntactic structures and morphological information, 25-56. Mouton de Gruyter, Berlin \& New York. 
Cho, Eun 1997. Counterfactuals in Korean and Japanese: Interaction between verbal morphology and interpretation. Manuscript. Cornell University.

Chomsky, Noam 2001. Derivation by phase. In: Michael Kenstowicz (ed.): Ken Hale: A life in language, 1-52. MIT Press, Cambridge MA.

Cinque, Guglielmo 1999. Adverbs and functional heads: A cross-lingustic perspective. Oxford University Press, New York \& Oxford.

Condoravdi, Cleo 2001. Temporal interpretation of modals. In: David Beaver-Stefan Kaufmann - Brady Clark - Luis Castillas (eds): Stanford papers on semantics, 1-30. CSLI Publications, Stanford.

Drubig, Hans Bernhard 2001. On the syntactic form of epistemic modality. Manuscript. University of Tübingen.

(http://www.sfb441.uni-tuebingen.de/b2/papers/DrubigModality.pdf)

É. Kiss, Katalin 2004. A nézőponti aspektus jelölésétől a szituációs aspektus jelöléséig [From marking viewpoint aspect to marking situational aspect]. Paper presented at the Seventh International Congress of Hungarian Linguistics, August 2004, Budapest.

É. Kiss, Katalin 2005. Az ómagyar igeidőrendszer morfoszintaxisáról [On the morphosyntax of the tense system of old Hungarian]. Paper presented in the Research Institute for Linguistics, Hungarian Academy of Sciences, 10 February 2005, Budapest.

Eszes, Boldizsár 2004. Világidők és lehetőségek: új fejlemények a modális eseményszemantikában [World times and possibilities: New developments in modal event semantics]. In: Balázs Sinkovics (ed.): LingDok 4. Nyelvész doktoranduszok dolgozatai [LingDok 4. Papers by students of linguistics], 23-45. JATEPress, Szeged.

Farkas, Donka F. 1992. Mood choice in complement clauses. In: István Kenesei-Csaba Pléh (eds): Approaches to Hungarian 4 (The structure of Hungarian), 207-25. JATE, Szeged.

Iatridou, Sabine 2000. The grammatical ingredients of counterfactuality. In: Linguistic Inquiry $31: 231-70$.

Kálmán, László (ed.) 2001. Magyar leíró nyelvtan. Mondattan I [Hungarian descriptive grammar. Syntax 1] (Segédkönyvek a nyelvészet tanulmányozásához VI [Supplementary textbooks on linguistics 6]). Tinta Kiadó, Budapest.

Karttunen, Lauri 1972. Possible and must. In: J. P. Kimball (ed.): Syntax and semantics, vol. 1, 1-20. Academic Press, New York.

Kiefer, Ferenc 1981. What is possible in Hungarian? In: Acta Linguistica Hungarica $31: 147-85$.

Kiefer, Ferenc 1985. A -hat/-het képző jelentéstanához: az episztemikus -hat/-het [On the semantics of the modal suffix -hat/-het: Epistemic -hat/-het]. In: Általános Nyelvészeti Tanulmányok $16: 131-53$.

Kiefer, Ferenc 2005. Lehetőség és szükségszerüség. Tanulmányok a nyelvi modalitás köréből [Possibility and necessity. Studies in the domain of linguistic modality]. Tinta Könyvkiadó, Budapest.

Kratzer, Angelika 1981. The notional category of modality. In: Hannes Rieser-HansJürgen Eikmeyer (eds): Words, worlds, and contexts, 38-74. Walter de Gruyter, Berlin. 
Kratzer, Angelika 1991. Modality. In: Arnim von Stechow-Dieter Wunderlich (eds): Semantik/semantics: An international handbook of contemporary research, 63950. Walter de Gruyter, Berlin.

Rákosi, György 2001. Mód és modalitás a magyarban [Mood and modality in Hungarian]. Paper presented at the Fourth Linguistics Conference for Doctoral Students (LingDok 4), Szeged.

Rebrus, Péter 2000. Morfofonológiai jelenségek [Morphophonological phenomena]. In: Ferenc Kiefer (ed.): Strukturális magyar nyelvtan 3. Morfológia [A structural grammar of Hungarian, Vol. 3: Morphology], 763-947. Akadémiai Kiadó, Budapest.

Tóth, Enikő 2006. Az alárendelt mondatbeli módválasztásról [On mood choice in subordinate clauses]. In: Balázs Sinkovics (ed.): LingDok 5. Nyelvész-doktoranduszok dolgozatai [Papers by doctoral students of linguistics], 181-200. JATEPress, Szeged.

Westmoreland, Robert R. 1995. Epistemic must as evidential. In: Paul Dekker-Martin Stokhof (eds): Proceedings of the 10th Amsterdam Colloquium, Part III, 683702. ILLC, University of Amsterdam, Amsterdam. 